\title{
INNOVATION AND INTERNATIONALIZATION: RELATIONSHIP AND IMPLICATIONS FOR MANAGEMENT AND PUBLIC POLICY
}

\author{
JOAn FREIXANET ${ }^{7}$ \\ Graduate School of Management, Saint Petersburg University, Volkhovsky per., 3, 199004, Saint \\ Petersburg, Russia.
}

\begin{abstract}
Innovation and internationalization are two basic growth strategies which contend for both the firms' and governments resources. At the same time, they are linked by a two-way relationship that has been widely documented in previous studies. However, often preceding literature is disconnected and does not integrate innovation and export promotion studies into the analysis. In this article we review and synthesize the different approaches regarding these relationships, while considering also the research on the impact of export promotion programs. As a result, a list of recommendations is deduced both for management and public policy regarding the development of these two strategies.
\end{abstract}

\section{KEYWORDS}

innovation, growth strategy, export performance, internationalization, profitability.

\section{INTRODUCTION}

Innovation and internationalization are two basic methods for companies' growth and competitiveness. At the same time, they contend for both the firms' and for government resources. Managers, especially those of Small to Medium-Sized Enterprises (SMEs), handle scarce financial and human resources, and must decide which option will bring about the highest profits, both on the short and long term, and has therefore priority: investing in R\&D with the aim of developing new or better products/ processes; or prioritize opening new markets, and offering internationally their existing products. Governments and public administration in general, must also decide what will result in more public benefits such as employment and economic growth: either allocate public budget in order to foster companies' innovation, or use the resources to create export agencies and programs that help firms to grow internationally.

At the same time, innovation and internationalization are intrinsically related, and are therefore not only substitutable but complementary: when companies enter in a foreign country they are exposed to a different market context, which may help/ force them to innovate regarding their products or processes.

Another factor to consider is that internationalization is also a result of product innovation. The more innovative companies are more likely to be successful in the international markets. Furthermore, the investments firms carry out in R\&D need to be justified by a large enough amount of sales. Thus, many firms may be motivated to start an internationalization process, out of their

\footnotetext{
${ }^{7}$ Tel.: +34 626823 722. E-mail address: juan.freixanet@upf.edu
} 
need to achieve economies of scale in their R\&D budget; that is to say, with the goal to distribute innovation costs among more units.

There is abundant literature, often disconnected, on the relationship between innovation and internationalization. There is the need to synthesize the different approaches and results, because from the comparative analysis it is possible to extract useful conclusions.

In parallel, different studies have been carried out on the effects of the assistance from government to help companies to grow in the international markets (export promotion programs), and to foster their innovation (innovation promotion programs). It is necessary to integrate these into the analysis, and use the knowledge in both fields in order to improve public programs. There are several important motivations for developing a comprehensive analysis in this field. The first one is the need to help export and innovation promotion organizations to improve program design, adapt programs to company requirements and create better implementation procedures. The second motivation is the importance of increasing the programs' credibility in the eyes both of public opinion and of governments, which ultimately finance them. Finally it is necessary to give company managers information about the role programs can play in their organizations, and how to make the most of them.

This article is structured in the following way: first, we refer to the firms' internationalization process; second, we define and describe the export promotion programs and then the innovation promotion programs; third, we review the previous literature on the relationship between innovation and internationalization; finally, we extract some conclusions and some implications for the design and implementation of programs and for managers.

\section{LITERATURE REVIEW}

\subsection{The Company's Internationalization Process}

The firms' process of expansion in the international markets is characterized by several key decisions. These start with the motivations to start exporting (why), continue with the selection of the target market (where), the entry mode choice (how), and end with the adaptation of the company to the international environment (Prashantham, 2005).

However, it is necessary to emphasize that this is not a static but a dynamic process. That is to say, companies periodically change the reasons to be present in the international markets (for instance from reactive motivations to proactive ones), their target markets (normally from the markets that are closer culturally and geographically, to more distant ones), and their entry modes (from the most simple ones, such as agents and distributors, to more complex such as branch offices or subsidiaries).

In fact, in line with the Uppsala theory (Johanson \& Vahlne, 1977), we can see that firms go through different stages in their internationalization process, gradually increasing their involvement with the foreign markets. There have been different attempts to define how many stages the company goes through in this process. For example, Johanson \& Wiedersheim-Paul (1975) distinguished 4 stages, going from reactive exporters to multinational company. Barret \& Wilkinson (1986), introduced a new stage, differentiating between companies that have never exported from those that did it in the past -even though now they are not doing it anymore, as more advanced; besides, they also consider those companies that have established production subsidiaries abroad as 
more advanced in the internationalization process. Cavusgil (1980) also proposed a 5 stages model, going from the non-exporting company, to the one with a high export commitment ${ }^{8}$.

In Freixanet (2012) these approaches are synthesized in a 5 stage model. Companies are classified into one or other stage depending on four variables, which complement each other in determining the level of involvement and skills regarding internationalization, the two main attributes that determine the evolution through the different stages:

- Export volume: the amount of sales in foreign markets is one of the main indicators of the level of a company's international involvement. To achieve these sales companies must invest in production infrastructure, personnel, inventory, marketing, etc. Therefore, the level of exports is related to the importance of the commitment of resources for the international markets; also, more skills will usually be needed to achieve and maintain these international sales.

- Size of the export or international expansion department: this classification variable relates to the previous one. A higher number of employees working in international business implies a higher commitment of resources for the export department (increase in salaries, travelling expenses, office space, etc.). As suggested by different authors (Cavusgil, 1983; Gray, 1997; Reid, 1984), skills will also increase with more professionals contributing their knowledge, experience and efforts to internationalization.

- Creation of permanent establishments abroad (branch offices or sales subsidiaries): this variable implies a further step in a company's internationalization, since it entails investing in personnel, legal formalities, renting or buying the business premises... It also raises exit barriers, making it more difficult giving up internationalization. Furthermore, it implies the company will have to develop a set of skills (international management, adaptation to different legal environments. . .), which is wider than the one from exporters which have not created permanent establishments.

- Creation of a production subsidiary: all the factors of international involvement related to sales establishments are enhanced when a production subsidiary is created. The firm must invest not only in the sales area but also in the rest of the departments (technicians, managers, production employees, machinery, inventory, etc.). Significant exit barriers are thus created, and consequently, producing abroad is a decisive step in the company's internationalization. Moreover, using this entry form implies that extensive information is needed on topics such as the tax or labor legal system, the law regarding foreign investment, logistics inside the country and with the company's country, etc. The firm will, therefore, develop a set of more advanced skills than those of companies in the previous stages (Barret \& Wilkinson, 1986).

According to these criteria, companies could be classified into 5 stages, as shown in Table 1.

Table 1 Classification criteria by internationalization stage, based on the level of involvement with foreign markets

\begin{tabular}{|l|l|l|l|l|}
\hline STAGE & $\begin{array}{l}\text { Exports } \\
(€ \mathrm{~m})\end{array}$ & $\begin{array}{l}\text { Permanent } \\
\text { Establish- } \\
\text { ments }\end{array}$ & $\begin{array}{l}\text { Employees } \\
\text { Export } \\
\text { Department }\end{array}$ & $\begin{array}{l}\text { Internationalization } \\
\text { Involvement / Skills }\end{array}$ \\
\hline 1. Starting/ passive Exporter & $1-299$ & NO & & Low \\
\hline 2. Regular Exporter with little structure & $>300$ & NO & $<=3$ & Low - Medium \\
\hline
\end{tabular}

\footnotetext{
${ }^{8}$ See appendix for a synthesis of all the main stages models.
} 


\begin{tabular}{|l|l|l|l|l|}
\hline 3. Regular Exporter with complete structure & $>300$ & NO & $>3$ & Medium \\
\hline $\begin{array}{c}\text { 4. Consolidated Exporter with permanent } \\
\text { sales or logistic establishments }\end{array}$ & $>2500$ & YES & $>3$ & High \\
\hline $\begin{array}{c}\text { 5. Industrial Multinational with production } \\
\text { subsidiaries abroad }\end{array}$ & $>2500$ & YES & $>3$ & Very high \\
\hline
\end{tabular}

\subsection{Export Promotion Programs (EPPs)}

In many countries, public and private institutions have created a whole set of services, with the aim of helping companies to overcome export obstacles. That is to say, barriers that prevent firms from making the most from foreign markets, and that may be classified in three types: lacking the motivation or willingness to export, not having enough export capabilities/ skills for it, and finally, not possessing the required human or financial resources.

Thus, the purpose of EPPs is to help firms advance through the different stages of the internationalization process. First from being merely passive exporters, to developing regular exports; then, by increasing international sales, to create a complete export department; finally, EPPs help companies to create branch offices or subsidiaries abroad, thus reaching stages 4 or 5 in the internationalization process 9 .

Ultimately, government export promotion agencies and programs are established with the underlying belief that export activities contribute substantially to the economic and social development of the country (Czinkota \& Kotabe, 1992; Lederman et al., 2010; Seringhaus \& Botschen, 1991).

The services they offer depend on the country's level of economic development. In many developing economies, the most frequent programs are specialized in helping companies access the necessary financial resources to export, such as loans, or to technology (Alvarez, 2004; Naidu et al., 1997). Instead, in more developed countries, the most popular programs usually include the following:

- Trade missions: visits organized for groups of managers with a view to allow them a first contact with a foreign market.

- Sponsored foreign trade shows: they enable companies to participate in an exhibition abroad with a partly or totally sponsored cost.

- Foreign trade offices: branches of the export promotion agency abroad, with a view to help companies make local contacts, get market information, etc.

- Information and Training programs: including seminars, courses, specialized publications, market surveys...

Examples of export promotion agencies can be found at the state or national level, such as the Spanish ICEX (España Exportación e Inversiones), ACCIO from Catalonia Autonomous

\footnotetext{
${ }^{9}$ For example, the ICEX, main Export Promotion Organization in Spain, segments its programs depending on these stages. They divide them in programs for starting exporters, regular exporters, and programs for companies who intend to establish foreign subsidiaries. For these latter, they provide different services such as specific information and financing.
} 
Community, the Canadian Trade Commissioner Service (TCS), CzechTrade from the Czech Republic, or UBIFRANCE -national agency from France, among many others.

\subsection{Innovation Promotion Programs}

Innovation promotion programs and agencies are also present in most countries. They are created in order to foster the development of new products, processes or services in companies. Governments' budget is allocated to such programs with the final goal of making firms more competitive and efficient, so that they may develop and in consequence result in the growth of GDP and the creation of employment. The main programs consist of different measures such as:

- Access to loans or to grants for innovative projects or companies.

- Innovation training: giving the company some knowledge and tools on how to innovate, through courses or publications with such topics as design thinking, innovation strategies, change management, project management, creativity...

- Technology transfer from Universities and Research Centers.

- Technological Consultancy: advice on how to develop innovative products or processes.

- Assistance in networking and the search of partners: technological, financial...

Examples of agencies offering all or part of these services are the Spanish CDTI (Centro para el Desarrollo Tecnológico Industrial), the French ANR (Agency Nationale de la Recherche), Industry Canada, or the AIE (Association of Innovative Entrepreneurship) from the Czech Republic.

The reciprocal effects between Innovation and Internationalization have been broadly described in preceding research. The different studies may be classified in five different types depending on their conclusions. They are summarized in Table 2 at the end of this section and described next.

\subsubsection{Studies concluding a reciprocal relationship between Innovation and internationalization}

Many previous studies have concluded that a virtuous circle takes place between the two concepts, one reinforcing the other. Esteve-Pérez \& Rodríguez (2013) using a sample of Spanish manufacturing SMEs, determined the existence of a strong interdependence between export and R\&D activities. According to their results, engaging in export (R\&D) activities will increase a firm's chances of also engaging in $R \& D$ (export) activities. This, in turn, increases firms' chances of succeeding in export $(\mathrm{R} \& \mathrm{D})$ activities.

Also, Filippetti et al. (2011) examined the relationship between countries' international profile and their innovation performance using data for 32 European countries. Using empirical correlations between innovation and several indicators of internationalization, they also established this double association: innovative firms are more successful in competing internationally and the exposure to alternative business and innovation contexts leads to innovation.

In the same vein, Halilem et al. (2013) stated that "these two major sources of growth are linked by different sets of relations, from the investment in product and process innovation to outward internationalization in a closer market, or from inward and outward internationalization in farther markets to the investment in product innovation." 


\subsubsection{Studies concluding a reciprocal relationship between Innovation and internationalization}

Pittiglio et al. (2009) analyzed the impact of international activities on knowledge output. For this purpose, they employed a dataset containing qualitative information about a sample of Italian manufacturing SMEs. Using a probit model they found that firms active in international markets generate more knowledge than their counterparts which sell in the national market only.

In turn, Aw et al. (2009) linked export market participation, investments in R\&D and worker training, and firm productivity, and quantified the relationships using firm level data for the Taiwanese electronics producers. They found that "for the electronics industry export market participation is more than just the self-selection of more efficient firms into the export market. We find evidence consistent with the learning-by-exporting hypothesis whereby firms that export have significantly higher productivity growth than those that do not export. The robustness of the relationship between exports and future productivity suggests that the export activity is an important mechanism for technology transfer in this industry." (p. 103). Thus, this study supports the effects of the internationalization process on innovation for this particular industry (electronics) and country (Taiwan).

How may internationalization have an impact in innovation? According to Kiriyama (2012) there are three channels through which these effects may take place: first, by imports, foreign direct investment (FDI) and trade in technology as means of technology diffusion; second, imports, FDI and technology transfer which intensify competition and thus increase incentives to innovate; and third, exports which offer learning opportunities and provide incentives for innovation.

\subsubsection{Studies that question the learning by exporting effect}

However, the "learning by exporting" effect is put into question by several authors. Bratti and Felice (2012) point out that "relatively few studies show that export fosters innovation".

Also, several studies by Hobday, 1995; Westphal, 2002 ${ }^{10}$ using various methodologies and data sets, point out that econometric analyses of firm or plant-level data provide little evidence of any learning-by-exporting. They concluded that the higher productivity generally exhibited by exporting firms can be better explained by the self-selection of more efficient firms into the export market rather than by any learning-by-exporting.

A good argument regarding the different points of view is provided by Altamonte et al. (2013). They maintain that there is some support for the 'learning by exporting' channel typically for countries-industries behind the best practice frontier, as it may be seen in Van Biesebroeck (2005), or in De Loecker (2007). In these cases it would be clear that companies obtain from the contact with foreign markets and competitors the knowledge they need in order to improve their products. They may innovate and in consequence become more competitive, both for the international and domestic markets. This may well be the case of the study from Aw et al. (2009) in the electronics industry in Taiwan.

\subsubsection{Studies that conclude that innovation favors internationalization}

The opinion about an overall relationship in the sense of innovation favoring internationalization seems to be unanimous. The more innovative companies may develop better or more adapted products, and this in turn result in more opportunities to commercialize the products around the world.

\footnotetext{
${ }^{10}$ Cited in Aw et al. (2009).
} 
For example, Lamotte \& Colovic (2010) investigated the relationship between innovation and internationalization in young entrepreneurial firms. Based on data from the Global Entrepreneurship Monitor and the World Bank for 64 countries during the 2001-2008 period, they demonstrated that young entrepreneurial firms involved in product and/or process innovation are more likely to be internationalized. Moreover, their results revealed that the impact of innovation is greater for product innovation than for process innovation.

In turn, Rios-Morales and Brennan (2009) demonstrated that continual policy innovation on the part of government can mean a relevant contribution to firms' process of internationalization. They measured governments' influence on FDI in Ireland and concluded that innovation is one of the keys to the success of the Irish model of internationalization.

Basile (2001), by using a sample of Italian manufacturing firms, found that innovation capabilities are very important competitive factors and help explain heterogeneity in export behavior among companies. He concluded that the export intensity of innovating firms is systematically higher than that of non-innovating firms.

Becker \& Egger (2009) provided an empirical analysis of the effects of new product versus process innovations on export propensity at the firm level. They concluded that product innovation is a key factor for successful market entry. Process innovation, in turn, helps securing a firm's market position given the characteristics of its product supply. According to the authors, both modes of innovation are expected to raise a firm's propensity to export, but product innovation is relatively more important in that regard.

According to Kafouros et al. (2008), the degree of internationalization is a central mediator of the relationship between innovation and performance. By being present in international markets, firms can better exploit their R\&D investments.

In turn, Bannò et al. (2013), took Italian regions as a unit of analysis, and examined the interrelationships between public grants, level of innovation and internationalization and economic performance. Their main findings were that the impact of pro-innovation policies on economic output (measured by regional GDP) is higher in internationalized regions. As they point out, their findings suggest re-thinking industrial policy-making. However, they do not propose any specific measures on how to do this.

It is also noteworthy to mention Amaral et al. (2014), who investigated the internationalization success factors of service SMEs. They focused on the managers' entrepreneurial orientation (EO), measuring it through 5 dimensions: risk taking, aggressiveness, autonomy, proactivity and innovation. The results pointed out to innovation ${ }^{11}$, together with proactivity, as the fundamental elements for international success. The findings also coincide with Becker \& Egger (2009) regarding the importance of "product innovation": successful companies have emphasized changes enabling the adaptation of their services to their clients, while unsuccessful ones have mainly implemented changes within their organizations (process innovation).

Interestingly, the study also identified a complementary resource, networking, which may be a mediating variable regarding the effects of innovation on export performance. This would work in the sense that, having a large and strong network of partners in the foreign markets, would help the company to obtain the information it needs in order to develop a more effective and efficient

\footnotetext{
${ }^{11}$ Innovation in this context referred to the creative capacity, and the necessary flexibility and knowledge, to adapt to new markets and to personalize the offered solutions.
} 
innovation. Reciprocally, the most innovative companies would attract the best partners, thus establishing a virtuous circle between networking and innovation.

Another interesting element to bear in mind regarding the reciprocal relationship between the investment in R\&D and internationalization, is that it's characterized by inter-temporal linkages (Roberts \& Tybout, 1997; Bernard \& Jensen, 1999, 2004; Geroski et al., 1997). That is to say, the effect of one in the other is felt only after a period of time. This places SMEs with less financial resources at a disadvantage, since they may lack the financial muscle necessary to face an investment that they will only recover after a considerable amount of time (Wright et al., 2007). This is more so given that in most cases obtaining revenues internationally requires more time than in the domestic markets ${ }^{12}$.

1.3.5. Studies that conclude that innovation favors internationalization through the moderating effects of the variable "productivity"

This line of research studies how the innovation efforts from companies may have an impact in firms' productivity, and consequently, enable them to achieve export performance.

In this vein, Cassiman \& Golovko (2011) showed, by using a sample of Spanish manufacturing firms, that product innovation, through its effect on firm productivity, increases the likelihood of the firm entering the export market. They argued that the strong positive association found between firm productivity and exports in the literature relates to the company's earlier innovation decisions, and that, when controlling for product innovation, the relationship between productivity and exports vanishes for these innovating firms.

Similarly, Lileeva \& Trefler (2010), in a study carried out in Canada, concluded that the decisions to venture in the international markets and to invest in increasing the productivity are positively related, and may be complementary for productivity growth.

Thus, as Hopenhayn (1992) pointed out, companies which have been able to become more productive and efficient survive and grow in the market, while inefficient ones, are not successful and tend to decline.

Also, according to Cassiman \& Martinez-Ros (2007). export decisions have been related to better performing firms, where causality seems to run from good performance to entering export markets. Their results suggest that product innovation rather than process innovation affects firm productivity, which in turn enables firms to enter into the international markets.

In the same sense of reasoning as we did before, some authors suggest the opposite effects direction may be true. Salomon \& Shaver (2005), indicate that exporters may learn from their foreign contacts, adopting new production technologies and thereby increasing their productivity and performance. However, the most unanimous conclusion is that exporters have higher productivity than non-exporters before starting the internationalization process, and no significant productivity advantages are observed among continuous exporters or non-exporting firms respectively over time (Aw, Chen, \& Roberts, 2001; Bernard \& Jensen, 1999; Damijan \& Kostevc, 2006; Delgado et al., 2002; Fafchamps, El Hamine, \& Zeufack, 2007; Greenaway \& Kneller, 2007) ${ }^{13}$. Therefore, again, the unanimous direction of causality is not that internationalization brings about an increase in

\footnotetext{
${ }^{12}$ The transaction costs and time involved in international sales increase because companies need to find the market information they do not yet possess, promote a brand usually still unknown in the target country, develop the distribution networks, and so on.

${ }^{13}$ Cited in Cassiman and Golovko (2011).
} 
productivity, but the contrary: the more productive firms, are more competitive and therefore may sell better their products in the international markets.

In summary, as shown in Figure 1, the results point out unanimously to the positive impact of innovation in firms' internationalization, with some research including "productivity" as a moderating variable. The effects on the other direction (from internationalization into productivity, or directly into innovation) have been argued in some studies, although they seem only clear in some specific cases and economic contexts.

Figure 1 Model of relationship between Innovation and Export Performance

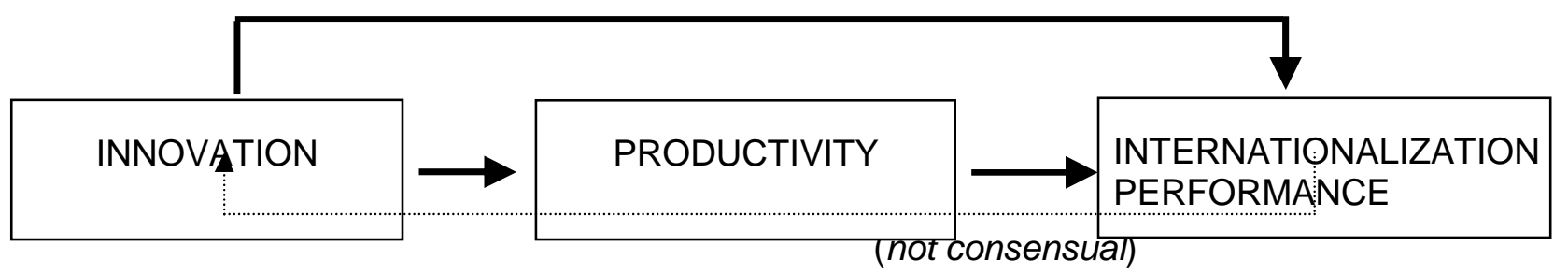

Table 2 Summary of the different models and conclusions

\begin{tabular}{|l|l|l|l|}
\hline \multicolumn{1}{|c|}{ Title } & \multicolumn{1}{|c|}{ Author } & Location & \multicolumn{1}{c|}{ Description/ Findings } \\
\hline \multicolumn{2}{|c|}{ a. Studies concluding a reciprocal relationship between Innovation and internationalization } \\
\hline $\begin{array}{l}\text { The dynamics of } \\
\text { exports and R\&D in } \\
\text { SMEs }\end{array}$ & $\begin{array}{l}\text { Esteve- } \\
\text { Pérez \& } \\
\text { Rodríguez } \\
(2013)\end{array}$ & Spain & $\begin{array}{l}\text { Engaging in export (R\&D) activities will increase a } \\
\text { firm's chances of also engaging in R\&D (export) } \\
\text { activities. This increases firms' chances of succeeding in } \\
\text { export (R\&D) activities. }\end{array}$ \\
\hline $\begin{array}{l}\text { Are Innovation and } \\
\text { Internationalization } \\
\text { Related? An Analysis } \\
\text { of European Countries }\end{array}$ & $\begin{array}{l}\text { Filippetti } \\
\text { et al. } \\
(2011)\end{array}$ & Europe & $\begin{array}{l}\text { Innovative firms are more successful in competing } \\
\text { internationally and the exposure to alternative business } \\
\text { and innovation contexts leads to innovation. }\end{array}$ \\
\hline $\begin{array}{l}\text { Exploring relationship } \\
\text { between innovation and } \\
\text { internationaliz. of } \\
\begin{array}{l}\text { SMEs: A nonrecursive } \\
\text { S.E.M.. }\end{array}\end{array}$ & $\begin{array}{l}\text { Halilem } \text { et } \text { (2013) } \\
\text { al. }\end{array}$ & Canada & $\begin{array}{l}\text { Different relations, from the investment in innovation to } \\
\text { internationalization in a closer market, or from } \\
\text { internationalization in farther markets to the investment } \\
\text { in product innovation. }\end{array}$ \\
\hline
\end{tabular}




\begin{tabular}{|c|c|c|c|}
\hline Title & Author & Location & Description/ Findings \\
\hline \multicolumn{4}{|c|}{ b. Studies concluding an effect of intemationalization in innovation } \\
\hline \begin{tabular}{l|} 
Innovation and \\
Internationalization: \\
The Case of Italy
\end{tabular} & $\begin{array}{l}\text { Pittiglio et al. } \\
(2009)\end{array}$ & Italy & $\begin{array}{l}\text { Firms active in international markets generate more } \\
\text { knowledge than their counterparts which sell in the } \\
\text { national market only. }\end{array}$ \\
\hline $\begin{array}{l}\text { R\&D investment, } \\
\text { exporting, and } \\
\text { productivity dynamics }\end{array}$ & Aw etal. (2009) & Taiwan & $\begin{array}{l}\text { Firms that export have significantly higher } \\
\text { productivity growth than those that do not export. } \\
\text { Export activity is an important mechanism for } \\
\text { technology transfer in electronics industry. }\end{array}$ \\
\hline $\begin{array}{l}\text { Trade and innovation: } \\
\text { synthesis report }\end{array}$ & Kiriyama (2012) & Global & $\begin{array}{l}\text { Internationalizationmay increase innovation: } 1 \text {. by } \\
\text { imports, FDI and trade in technology as means of } \\
\text { technology diffusion; } 2 \text {. Competition that increases } \\
\text { incentives to innovate; and 3.Learning-by-exporting }\end{array}$ \\
\hline Various articles & $\begin{array}{l}\text { Altamonte et al. } \\
\text { (2013). Van } \\
\text { Biesebroeck (2005), } \\
\text { De Loecker (2007) }\end{array}$ & \begin{tabular}{l|} 
Several \\
countries
\end{tabular} & $\begin{array}{l}\text { There is some support for the 'learning by exporting' } \\
\text { channel typically for countries-industries behind the } \\
\text { best practice frontier. }\end{array}$ \\
\hline \multicolumn{4}{|c|}{ c. Studies that question the learning by exporting effect } \\
\hline \begin{tabular}{l|} 
Are Exporters More \\
Likely to Introduce \\
Product Innovations?
\end{tabular} & $\begin{array}{l}\text { Bratti and Felice } \\
(2012)\end{array}$ & Italy & $\begin{array}{l}\text { Relatively few studies show that export fosters } \\
\text { innovation. }\end{array}$ \\
\hline Various articles & $\begin{array}{l}\text { Hobday (1995) } \\
\text { Westphal (2002) }\end{array}$ & & $\begin{array}{l}\text { Econometric analyses of firm or plant-level data } \\
\text { provide little evidence of any learning-by-exporting. }\end{array}$ \\
\hline \multicolumn{4}{|c|}{ d. Studies that conclude that innovation favors intemationalization } \\
\hline $\begin{array}{l}\text { Innovation and } \\
\text { Internationalization in } \\
\text { Young Entrepren. } \\
\text { Firms }\end{array}$ & $\begin{array}{l}\text { Lamotte \& Colovic } \\
(2010)\end{array}$ & $\begin{array}{l}64 \\
\text { countries }\end{array}$ & $\begin{array}{l}\text { Young entrepreneurial firms involved in product } \\
\text { and/or process innovation are more likely to be } \\
\text { internationalized }\end{array}$ \\
\hline $\begin{array}{l}\text { Ireland's innovative } \\
\text { governmental policies } \\
\text { promoting } \\
\text { internationalization }\end{array}$ & $\begin{array}{l}\text { Rios-Morales and } \\
\text { Brennan (2009) }\end{array}$ & Ireland & $\begin{array}{l}\text { Continual policy innovation on the part of } \\
\text { government can mean a relevant contribution to } \\
\text { firms' proces } 5 \text { of internationalization }\end{array}$ \\
\hline $\begin{array}{l}\text { Export behavior of } \\
\text { Italian firms over the } \\
90^{\prime} \text { 's. The role of } \\
\text { innovation }\end{array}$ & Basile (2001) & Italy & $\begin{array}{l}\text { The export intensity of innovating firms is } \\
\text { systematically higher than that of non-innovating } \\
\text { firms }\end{array}$ \\
\hline $\begin{array}{l}\text { Endogenous product vs } \\
\text { process innovation and } \\
\text { a firm's propensity to } \\
\text { export }\end{array}$ & $\begin{array}{l}\text { Becker \& Egger } \\
(2009)\end{array}$ & Germany & $\begin{array}{l}\text { Innovation raises a firm's propensity to export, but } \\
\text { product innovation is relatively more important in } \\
\text { that regard. }\end{array}$ \\
\hline $\begin{array}{l}\text { The role of internation. } \\
\text { in explain. innovation } \\
\text { performance }\end{array}$ & $\begin{array}{l}\text { Kafouros et al. } \\
(2008)\end{array}$ & $\begin{array}{l}\text { United } \\
\text { Kingdom }\end{array}$ & $\begin{array}{l}\text { By being pres ent in international markets, firms can } \\
\text { better exploit their R\&D investments }\end{array}$ \\
\hline $\begin{array}{l}\text { Public Policy for } \\
\text { innovation and } \\
\text { internationalization: are } \\
\text { they worth it? }\end{array}$ & Bannò et al. (2013) & Italy & $\begin{array}{l}\text { The impact of pro-imnovation policies oneconomic } \\
\text { output is higher in internationalized regions. }\end{array}$ \\
\hline $\begin{array}{l}\text { Entrepreneurship } \\
\text { orientation in service } \\
\text { SMEs: key res ource for } \\
\text { internationalization }\end{array}$ & $\begin{array}{l}\text { Amaral et al. } \\
(2014)\end{array}$ & Spain & $\begin{array}{l}\text { Innovation and proactivity are the fundamental } \\
\text { elements for international success. Networking is a } \\
\text { mediating variable of innovation in export } \\
\text { performance. }\end{array}$ \\
\hline Various articles & $\begin{array}{l}\text { Roberts \& Tybout, } \\
\text { (1997); Bernard \& } \\
\text { Jensen, (1999), 2004; } \\
\text { Geroski et al., (1997) }\end{array}$ & \begin{tabular}{l|} 
Different \\
Countries
\end{tabular} & $\begin{array}{l}\text { The reciprocal relation ship between the investment in } \\
R \& D \text { and internationalization, is that it's } \\
\text { characterized by inter-temporal linkages. }\end{array}$ \\
\hline
\end{tabular}


e. Studies that conclude that innovation favors internationalization through the moderating effects of the variable "productivity"

\begin{tabular}{|l|l|l|l|}
\hline $\begin{array}{l}\text { Innovation and } \\
\text { intemationalization } \\
\text { through exports. }\end{array}$ & $\begin{array}{l}\text { Cassiman \& Golovko } \\
(2011)\end{array}$ & Spain & $\begin{array}{l}\text { Innovation, through its effect on firm productivity, } \\
\text { increases the likelihood of the firm entering the } \\
\text { export market. }\end{array}$ \\
\hline $\begin{array}{l}\text { Access to foreign } \\
\text { markets raises plant- } \\
\text { level productivity... for } \\
\text { some plants }\end{array}$ & Lileeva \& Trefler(2010) & Canada & $\begin{array}{l}\text { Internationalization and investing in increasing } \\
\text { productivity may be complementary for } \\
\text { productivity growth. }\end{array}$ \\
\hline $\begin{array}{l}\text { Product innovation \& } \\
\text { exports: Evidence from } \\
\text { Spanish manufacturing }\end{array}$ & $\begin{array}{l}\text { Cassiman \& Martinez- } \\
\text { Ros (2007) }\end{array}$ & Spain & $\begin{array}{l}\text { Product innovation rather than process innovation } \\
\text { affects firm productivity, which in tum enables } \\
\text { firms' intemationalization. }\end{array}$ \\
\hline $\begin{array}{l}\text { Learning-by-exports: } \\
\text { New insights from } \\
\text { examining firm } \\
\text { innovation. }\end{array}$ & $\begin{array}{l}\text { Salomon \& Shaver } \\
\text { (2005) }\end{array}$ & Spain & $\begin{array}{l}\text { Exporters may learn from their foreign contacts, } \\
\text { adopting new technologies and thereby increasing } \\
\text { their productivity and performance. }\end{array}$ \\
\hline Various articles & $\begin{array}{l}\text { Aw et al. (2001); } \\
\text { Bernard \& Jensen } \\
\text { (1999); Damijan \& } \\
\text { Kostevc (2006); } \\
\text { Delgado et al., (2002); } \\
\text { Fafchamps et al. (2007); } \\
\text { Greenaway \& Kneller; } \\
\text { 2007) }\end{array}$ & $\begin{array}{l}\text { Diffe- } \\
\text { rent } \\
\text { coun- }\end{array}$ & $\begin{array}{l}\text { Exporters have higher productivity than non- } \\
\text { exporters before starting the internationalization } \\
\text { process, and no significant productivity } \\
\text { advantages are observed among continuous } \\
\text { exporters or non-exporting firms respectively over } \\
\text { time }\end{array}$ \\
\hline
\end{tabular}

\section{CONCLUSIONS AND DISCUSSION}

Companies go through different stages in their internationalization process, gradually increasing the involvement with the foreign markets, as well as their export skills.

In many countries governments have created some programs to help firms advance in this process, and others to foster their innovation achievements.

Governments, the same as companies, face a strategic dilemma. They should decide whether to prioritize the allocation of resources to foster innovation, with the hope that businesses will develop better and more internationally successful products; or they should mostly use their budget to help companies sell their existing products abroad.

We may link both fields of research in order to deduct interesting conclusions regarding public policy and business management: one that relates innovation to export performance, and the other one associating export promotion programs to export success.

The previous studies reviewed above have given clear evidence on the positive effects of innovation on the firms' internationalization performance. This would point out to the need to prioritize innovation programs, with the aim of enhancing firms' competitiveness.

What about export promotion programs (EPPs)? Can we also deduct a direct influence on firms' internationalization performance? Different studies have measured the effects of export assistance on firms' international activity. Gençtürk and Kotabe (2001) concluded that EPPs bring about results primarily in export diversification and profitability, rather than in export sales. Francis and Collins-Dodd (2004) also found a positive relationship between program use, and impact measures related to company objectives, strategies and competencies, but not with economic measures. Fayos 
(2003) concluded that companies receive only indirect benefits from promotion (improvement in managers skills and sales leads), but not direct benefits (economic results). Seringhaus (1984) did not find a relationship between the use of a program (trade missions) and two performance outcomes (export intensity and number of orders), but it did with other indirect indicators, such as the number of export contacts. Finally, in Freixanet (2012), the global EPP impact analysis showed a relationship between use of programs and some marketing improvements; for instance, companies that used the programs developed more their sales networks, and had better promotion activities. However, the results showed no relationship with an increase in the firm's international sales.

Thus, the results from this group of studies provides evidence that EPPs help companies to develop some aspects which will make them more competitive, but their use is not related with an increase in exports. These findings are consistent with the objectives of EPPs: they are expected to help companies to better compete internationally, but the final achievement of exports depends on other variables beyond program control. Studies on innovation have established this is one of these key elements.

Besides, the results of the studies on EPPs impact seem to go in the same sense as the first group of studies we analyzed, supporting the learning-by-exporting thesis. Companies that use more EPPs enter in contact with the foreign markets, and thereafter they may become more innovative (and other dimensions of competitiveness such as improvements in their marketing, building sales networks...).

Furthermore, the analysis by type of program in Freixanet (2012) showed that the use of Direct Promotion Programs (such as trade missions and sponsored foreign trade shows), and the use of Information EPPs ${ }^{14}$ results in the creation of stronger and larger networks of foreign partners. This is one of the elements that we have argued previously will have an impact in the firm's innovation capabilities (and consequently in its export performance).

These results point out to some implications regarding the way Export and Innovation Promotion Programs are designed and managed, and their relationship ${ }^{15}$.

\section{$\underline{\text { Implications for Public Policy }}$}

The findings described above have implications on the program selection (which is the mix of services that should be prioritized), in their design (how they should be structured), their organization, and their segmentation (which kinds of companies should be preferably targeted):

- Studies in EPPs impact show that these, per se, are unlikeable to result in internationalization performance. Other elements, especially innovation, are required. In consequence:

- Export promotion agencies should prioritize companies that have developed innovative products or processes, when selecting those that will benefit from the scarce government funds dedicated to export assistance.

- Alternatively, companies with the potential to transform the information gathered through EPPs into innovation and then into exports, should also be considered first. Several indicators may be used in order to know the companies' innovation and exports potential. Among these we can suggest the managers' entrepreneurial orientation, reflected in such dimensions as risk-taking

\footnotetext{
${ }^{14}$ Includes information on markets, programs or export know-how, and use of foreign trade offices.

${ }^{15}$ A table with a summary of the findings and their implications for public policy and for managers is included at the end of this section.
} 
and proactivity (Covin and Slevin, 1989). The more entrepreneurial managers are the ones more likely to turn the assistance into international sales.

Additionally, given the necessary investment in both time and financial resources involved in collecting the information and in transforming it into marketable products (the "inter-temporal linkages" mentioned in previous section), another item to consider should be the possession of enough financial resources (or the capability to obtain them from financial institutions). The soundness of the balance sheet, the evolution of profits and turnover, may provide suitable measures for this factor.

- In line with Altamonte et al. (2013), we also recommend the coordination and integration of internationalization and innovation policies "under one roof" ${ }^{\prime \prime}$. In any case, these policies and programs should be further coordinated. For example, personnel of Export Promotion Organizations in contact with user companies, should be aware of Innovation programs and be willing to inform about them those interested in exporting.

Further measures could include making it easier for companies that have successfully participated in innovation programs, to use export services. For instance by granting them discounts on the possible EPPs fares, or by giving them preference over other companies.

- Governments should also make fostering business innovation one of their industrial policy priorities. Making available to companies a wide range of effective and well-designed Innovation Promotion Programs would be a necessary step. The complementary step should go in the sense of creating the conditions in order to make innovation easier, with measures that could include, among others: R\&D tax incentives such as credits or deductions; protection of intellectual property together with a favorable royalty payments tax regime; a swift-secure functioning of the markets, which attract investors and encourages risk-taking; the creation of dynamic higher and technical learning institutions; or the development of instruments of technology transfer from universities to companies (PWC, 2010).

- Research in the field of Export Promotion has shown that some EPPs (specifically Information and Direct Promotion Programs), help companies to create partner networks. Studies in the area of Innovation have found that it has a two-way relationship with networking. The linkage of both fields of research results in recommending that governments foster specially these specific programs, as a way to finally increase exports.

- The issues above address the topic of who will have more chances to transform the information coming from international markets into innovation and thereafter succeed in exporting. Complementarily, we should address the issue of for which companies export assistance can make more a difference. That is to say, which kind of companies would not be as successful if they didn't access export assistance; or looking on the other way, which firms do not need so much export assistance. Taking this into consideration, EPPs should be targeted as a priority to two types of companies, segmented according to their size and to their internationalization stage:

a) SMEs: in comparison to large firms, SMEs are more constrained by limited resources and capabilities for acquiring information and then transforming it into innovative products and

\footnotetext{
${ }^{16}$ The integration of Export and Innovation assistance is a process that, for example, already took place in the Autonomous Community of Catalonia (Spain). In Catalonia, the Export Promotion Agency (named COPCA), merged with the Innovation Promotion Agency (named CIDEM), and they created a common agency named ACCIO10. This process enabled the sharing of information, saving time for companies when asking for information, as well as economies of scope in administrative personnel and premises.
} 
processes. This makes them less likely to innovate and venture into exporting without government support. In fact, EPPs impact is typically higher among SMEs than larger firms (Zia, 2008; Freixanet, 2012).

b) Starting exporters: companies which are beginning their internationalization process need more support in order to develop their exports, training and information in order to become more competitive, and help in order to identify contacts and opportunities. This argumentation is supported by previous research, which found that firms in more advanced internationalization stages are the ones that perceive or experience less usefulness in EPPs (Freixanet, 2012; Francis \& Collins-Dodd, 2004; Czinkota, 1982; Seringhaus \& Rosson, 1990).

\section{$\underline{\text { Implications for Firms' Managers }}$}

The combination of findings described above have also some consequences on the business strategies:

- Companies should make innovation one of their most prevalent priorities. Firms that innovate obtain better products, are more productive, and thus achieve a higher export performance. These efforts may be complemented with actions to commercialize the products internationally (for example, prospection trips, participation in trade exhibitions, or contacts with distributors), but companies should not forget to give priority to innovation, since it is the basis of the future acceptance of their products in the international markets.

- Managers participating in EPPs should be conscious about the need to gather the information necessary for the improvement of their products and processes. They should come with a checklist of basic data to be obtained when establishing contact with the foreign markets, and that may bring about innovation, specially product improvement, which we have seen affects stronger internationalization than process innovation.

- Results show that SMEs and companies starting to export can become more competitive by using most available EPPs. Therefore, managers in companies from this segment should be especially active in gathering information about the programs and increasing their participation therein.

- Finally, managers must be aware that this is a long process. Gathering the information, transforming it into innovative products and systems takes time and requires a considerable amount of patience and an investment to be foreseen.

Table 3 Summary of findings and implications

\begin{tabular}{|c|c|c|}
\hline \multirow{2}{*}{ Findings } & \multicolumn{2}{|l|}{ Implications } \\
\hline & For Public Policy & For Managers \\
\hline \multirow{3}{*}{$\begin{array}{l}\text { EPPs, per se, are unlikeable to } \\
\text { result in export performance. } \\
\text { Other elements, especially } \\
\text { innovation, are required }\end{array}$} & $\begin{array}{l}\text { Prioritization of innovative companies in } \\
\text { EPPs, or with potential (for instance with } \\
\text { entrepreneurial managers). }\end{array}$ & \multirow{3}{*}{$\begin{array}{l}\text { Creation of a check-list } \\
\text { of basic data to be } \\
\text { obtained when } \\
\text { participating in EPPs, } \\
\text { and that may result in } \\
\text { product innovation. }\end{array}$} \\
\hline & $\begin{array}{l}\text { Coordination and integration of } \\
\text { internationalization and innovation policies } \\
\text { "under one roof". }\end{array}$ & \\
\hline & $\begin{array}{l}\text { Facilitate the exchanges between } \\
\text { innovation and export promotion programs. }\end{array}$ & \\
\hline
\end{tabular}




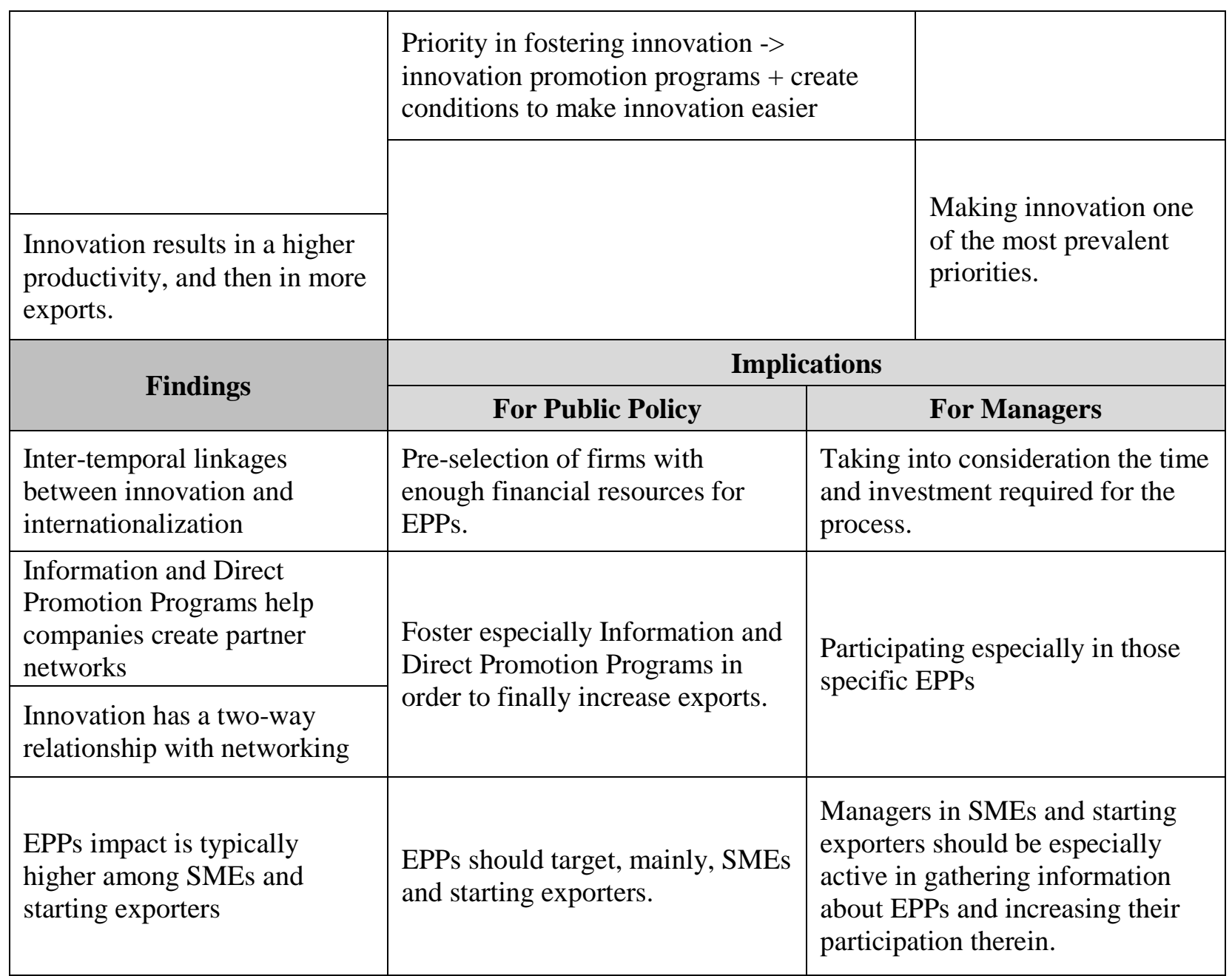

\section{SUGGESTIONS FOR FURTHER RESEARCH}

Previous studies have described the interactions between innovation and internationalization mainly for SMEs. An interesting contribution could be made by measuring how company size affects the impact. Specifically, it would be relevant to measure the effects for large multinationals. Contrary to SMEs, all these companies carry out R\&D activities, and therefore the marginal contribution of innovation may be expected to be less than for smaller organizations.

Additionally, an analysis by industry could provide most significant results, since the effects of innovation may be expected to be more decisive for some industries (for instance, technological industries, or those subject to an intense-global competition) than for others.

Finally, as shown in Table 2, the great majority of studies have been carried out in developed countries. Further research could be made as to the interactions between the two variables in emerging economies. It is expectable that the "learning-by-exporting" effects will be clearer for this category of countries. 


\begin{tabular}{|c|c|c|c|c|c|c|c|c|}
\hline 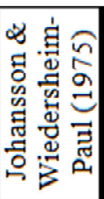 & 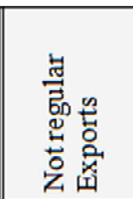 & 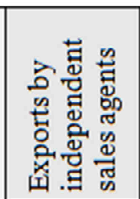 & 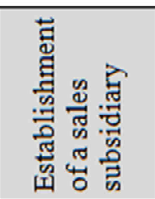 & 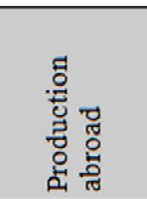 & & & & \\
\hline 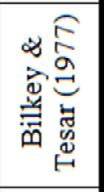 & 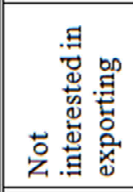 & 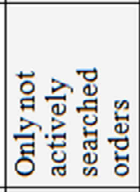 & 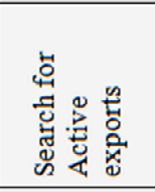 & 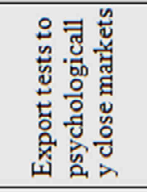 & 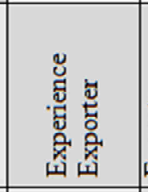 & 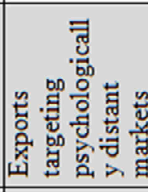 & & \\
\hline 素余 & 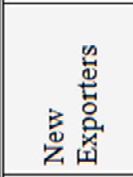 & 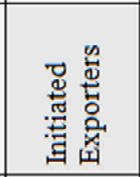 & 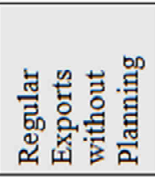 & 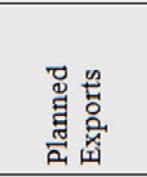 & 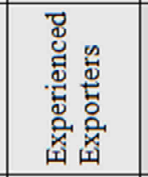 & 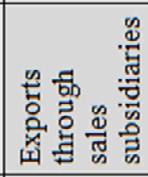 & 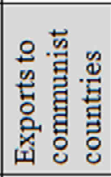 & \\
\hline 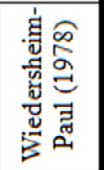 & 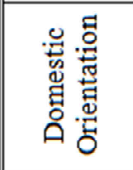 & $\begin{array}{l}\text { 总善 } \\
\text { 总 } \\
\text { 我离 }\end{array}$ & 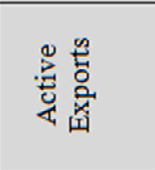 & & & & & \\
\hline 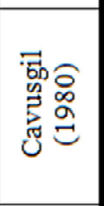 & 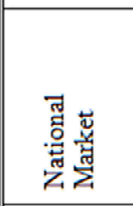 & 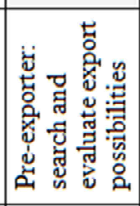 & 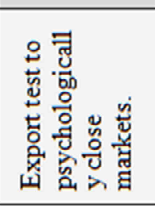 & 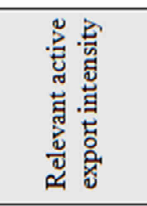 & 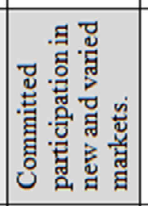 & & & \\
\hline 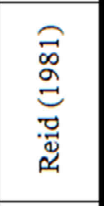 & 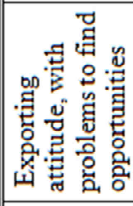 & 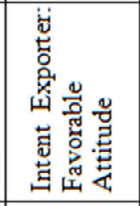 & 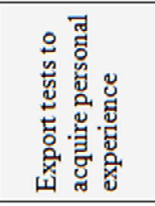 & 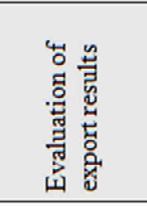 & 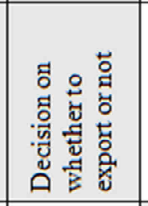 & & & \\
\hline 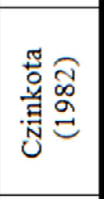 & 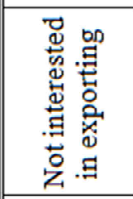 & 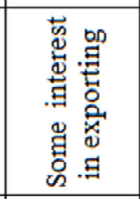 & 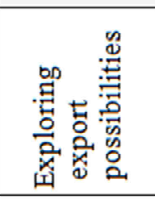 & 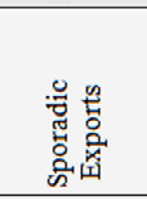 & 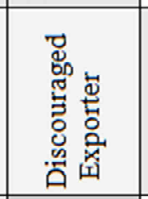 & 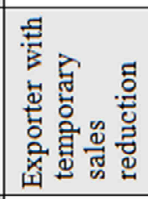 & 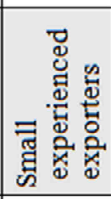 & 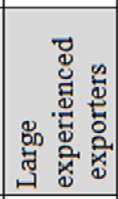 \\
\hline 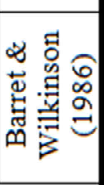 & 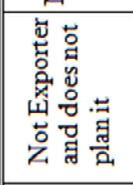 & 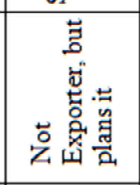 & 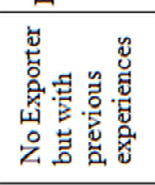 & $\begin{array}{l}\text { 密苋 } \\
\text { 总 } \\
\text { 畜 }\end{array}$ & 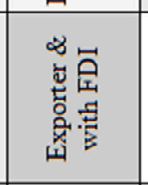 & & & \\
\hline 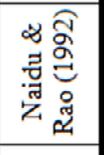 & 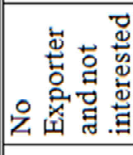 & 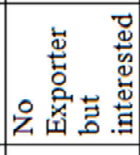 & 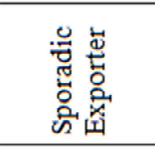 & 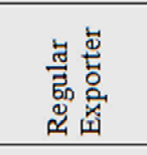 & & & & \\
\hline 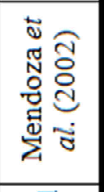 & 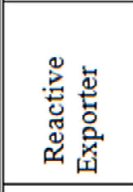 & 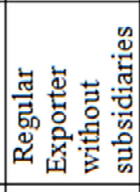 & 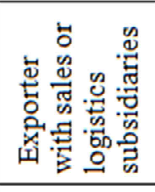 & 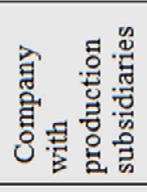 & & & & \\
\hline 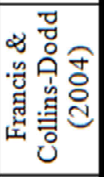 & 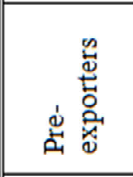 & 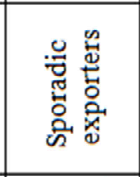 & 总 & 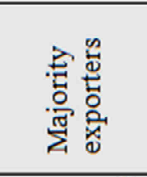 & & & & \\
\hline 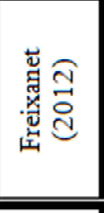 & 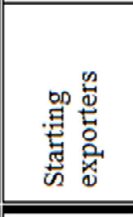 & 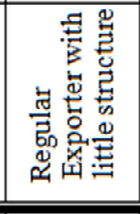 & 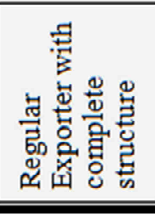 & 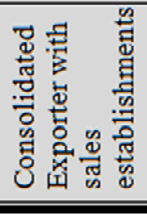 & 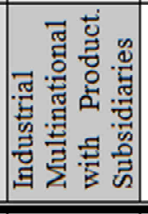 & & & \\
\hline & $\begin{array}{l}\vec{a} \\
\text { 品 } \\
\text { is }\end{array}$ & 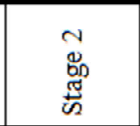 & 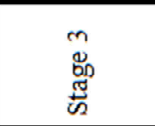 & 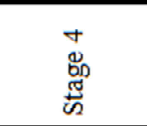 & 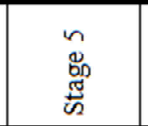 & 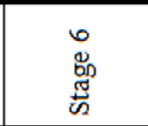 & 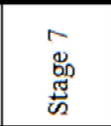 & $\begin{array}{l}\infty \\
\infty \\
\mathbb{0} \\
\mathbb{I} \\
0\end{array}$ \\
\hline
\end{tabular}




\section{REFERENCES}

Altomonete, C., Aquilante T., Békés G. \& Ottaviano G. (2013). Firm-level evidence on productivity differentials and turnover in Taiwanese manufacturing. Journal of Development Economics, 66 (1): 51-86.

Alvarez, R. (2004). Sources of export success in small- and medium enterprises: The impact of public programs. International Business Review, 13, 383-400.

Amaral, P., Freixanet J., Marquès P. (2014). Entrepreneurship orientation in service SMEs: key resource for internationalization. Paper presented in the INBAM Conference, Barcelona (Spain).

Aw, B. Y., Roberts, M. J., \& Xu, D. J. (2009). R\&D investment, exporting, and productivity dynamics, NBER Working Paper 14670, National Bureau of Economic Research, Cambridge, MA.

Aw, B. Y., Chen, X., \& Roberts, M. J. (2001). Firm-level evidence on productivity differentials and turnover in Taiwanese manufacturing. Journal of Development Economics, 66 (1): 51-86.

Bannò, M., Morandi, V. \& Amorim V., C. (2013). Public Policy for innovation and internationalization: are they worth it? Applied Economics Letters, 20 (10): 927-930.

Barret, N., \& Wilkinson, I. (1986). Australian management's attitudes to exporting - Past and present. Paper presented in the market research society of Australia's annual conference, Canberra.

Basile, R. (2001). Export behavior of Italian manufacturing firms over the nineties: The role of innovation. Research Policy, 30 (8): 1185-1201.

Becker, S. O., \& Egger, P. (2009). Endogenous product versus process innovation and a firm's propensity to export. Empirical Economics, doi: 10.1007/s00181-009-0322-6.

Bernard, A., \& Jensen, J. (1999). Exceptional exporter performance: Cause, effect or both? Journal of International Economics, 47 (1): 1-25.

Bernard, A., \& Jensen, J. (2004). Why some firms export. Review of Economics and Statistics, 86 (2): 561-569.

Bilkey, W.J. and Tesar, G. (1977). The export behaviour of smaller sized Wisconsin manufacturing firms. Journal of International Business Studies, Spr./Summer 1977, pp. 93-8.

Bratti, M., Felice, G. (2012). Are Exporters More Likely to Introduce Product Innovations? The World Economy, 35 (11): 1559-1598.

Cassiman, B., \& Martinez-Ros, E. (2007). Product innovation and exports: Evidence from Spanish manufacturing, IESE Working Paper, mimeo.

Cassiman, B.\& Golovko, E. (2011). Innovation and internationalization through exports. Journal of International Business Studies, 42(1), 56-75.

Cavusgil, S. T. (1980). On the Internationalisation Process of Firms. European Research, November 1980, pp 273-81.

Cavusgil, S. T. (1983). Success factors in export marketing: An empirical analysis. Journal of International Marketing and Marketing Research, 8(2), 63-73.

Covin, J.G. \& Slevin, D.P. (1989). Strategic management of small firms in hostile and benign environments. Strategic Management Journal, 10(1), 75-87.

Czinkota, M. R., \& Kotabe, M. (1992). State government promotion of manufacturing exports: A gap analysis. Journal of International Business Studies, 23(4), 637-658.

Czinkota, M. R. (1982b). An evaluation of the effectiveness of US export promotion efforts. In M. Czinkota \& G. Tesar (Eds.), Export policy: A global assessment (pp. 63-71). New York, NY: Praegar.

Damijan, J., \& Kostevc, C. (2006). Learning-by-exporting: Continuous productivity improvements or capacity utilization effects? Evidence from Slovenian firms. Review of World Economics, 142 (3): 599-614.

De Loecker, J. (2007). Do exports generate higher productivity? Evidence from Slovenia. Journal of International Economics , 73 (1): 69-98. 
Delgado, M., Farinas, J., \& Ruano, S. (2002). Firm productivity and export markets: A nonparametric approach. Journal of International Economics, 57(2): 397-422.

Esteve-Pérez S., Rodríguez D. (2013). The dynamics of exports and R\&D in SMEs. Small Bus Econ, 41: 219-240.

Fafchamps, M., El Hamine, S., \& Zeufack, A. (2007). Learning to export: Evidence from Moroccan manufacturing. Journal of African Economies, 17 (2): 305-335.

Fayos, T. (2003), La Evaluación de la Promoción Pública de la Internacionalización: Implicaciones sobre las Empresas Exporters de la Comunidad Valenciana. PhD dissertation, Universidad de Valencia.

Filippetti A., Frenz M., \& Ietto-Gillies G. (2011). Are Innovation and Internationalization Related? An Analysis of Europeaan Countries. Industry and Innovation, 18(5), 437-459.

Francis, J., \& Collins-Dodd, C. (2004). Impact of export promotion programs on firm competencies, strategies and performance - The case of Canadian high-tech SMEs. International Marketing Review, 4(5), 474-495.

Freixanet, J. (2012). Export promotion programs: Their impact on companies' inter-nationalization performance and competitiveness. International Business Review, 21(6), 1065-1086.

Geroski, P.A., Reenen J.V., Walters C.F. (1997). The effect of export assistance program usage on export performance. Journal of International Marketing, 9(2), 51-72.

Gençtürk, E. F., \& Kotabe, M. (2001). The effect of export assistance program usage on export performance. Journal of International Marketing, 9(2), 51-72.

Greenaway, D., \& Kneller, R. (2007). Firm heterogeneity, exporting and foreign direct investment. Economic Journal, 117 (517): 134-161.

Golovko, E., Valentini G. (2011). Exploring the complementarity between innovation and export for SMEs' growth. Journal of International Business Studies (2011) 42, 362-380.

Gray, B. J. (1997). Profiling managers to improve export promotion targeting. Journal of International Business Studies, Second Quarter, 387-420.

Halilem, N., Amara N., Landry R. (2013). Exploring the relationships between innovation and internationalization of small and medium-sized enterprises: A nonrecursive structural equation model. Canadian Journal of Administrative Sciences (2014) 31, 18-34.

Hobday, M. (1995a), Innovation in East Asia: The Challenge to Japan (Brookfield, VT: Edward Elgar).

Hopenhayn, H. (1992). Entry, exit and firm dynamics in long run equilibrium. Econometrica, 60 (5): 1127-1150.

Johanson, J., \& Vahlne, J. (1977). The internationalization process of the firm - A model of knowledge development and increasing foreign market commitments. Journal of International Business Studies, 8(1), 23-32.

Johanson, J., \& Wiedersheim-Paul, F. (1975). The internationalization of the firm - Four Swedish cases. Journal of Management Studies, 12, 305

Kafouros, M.I., Buckley, P.J., Sharp, J.A., et al. (2008). The role of internationalization in explaining innovation performance. Technovation, 28, 63-74.

Khan, S. (1978). A study of Success and Failure in Exports. EIBA.

Kiriyama, N. (2012). Trade and innovation: synthesis report, OECD Trade Policy Papers, 135.

Lamotte, O., Colovic A. (2010). Innovation and Internationalization in Young Entrepreneurial Firms. International Management, 18(1): 87-103.

Lederman, D., Olarreaga, M., \& Payton, L. (2010). Export promotion agencies: Do they work? Journal of Development Economics, 91, 257-265.

Lileeva, A., \& Trefler, D. (2010). Improved access to foreign markets raises plant-level productivity... for some plants. Quarterly Journal of Economics, 125(3): 1051-1099.

Mendoza, X., Sureda, J. \& Tornabell, R. (2002), Trajectòries d'internacionalit-zació de l'empresa catalana, Catalunya Internacional, COPCA, No. 32, pp. 3-8.

Naidu, G. M., Cavusgil, S. T., Murthy, B. K., \& Sarkar, M. (1997). An export promotion model for India: Implications for public policy. International Business Review, 6(2), 113-125. 
Naidu, G. M.; Rao, T.R. (1993). Public sector promotion of exports: a need-based approach, Journal of Business Research, Vol. 27, pp. 85-101.

Pavord, W. y Bogart, R. G. (1975). The Dynamics of the Decision to Export. Akron Business and Economic Review, Spring, pp. 6-11

Pittiblio, R., Sica E., Villa, S. (2009). Innovation and Internationalization: The Case of Italy. Journal of Technology Transfer, 34: 588-602.

Prashantham, S. (2005). Toward a knowledge-based conceptualisation of internationali-zation. Journal of International Entrepreneurship, 3(1), 37-52.

PricewaterhouseCoopers (2010). Government's Many Roles in Fostering Innovation. Innovation Report. 1-63.

Reid, S. (1984). Information acquisition and export entry decisions in small firms. Journal of Business Research, 12(2), 141-157.

Reid, S. (1981). The decision-maker and export entry and expansion. Journal of International Business Studies, vol 12, pp 101-12.

Ríos-Morales, R., Brennan L. (2009). Ireland's innovative governmental policies promoting internationalization. Research in International Business and Finance, 23(2), 157-168.

Roberts, M., \& Tybout, R. (1997). The decision to export in Colombia: An empirical model of entry with sunk costs. American Economic Review, 87 (4): 545-564.

Salomon R., \& Shaver J. M. (2005). Learning-by-exporting: New insights from examining firm innovation. Journal of Economics and Management Strategy, 14(2), 431-461.

Seringhaus, F. H. R. (1984). Government export marketing assistance \& medium-sized Ontario manufacturing firms: The role \& impact of trade missions on firms off-shore market involvement. PhD dissertation. York University, Toronto.

Seringhaus, F. H. R., \& Rosson, P. J. (1990). Government export promotion: A global perspective. London: Routledge.

Seringhaus, F. H. R., \& Botschen, G. (1991). Cross-national comparison of export promotion services: The views of Canadian and Austrian companies. Journal of International Business Studies, 22(1), 115-134.

Van Biesebroeck, J. 2005. Exporting raises productivity in sub-Saharan African manufacturing firms. Journal of International Economics, 67 (2): 373-391.

Westphal, L. E. (2002), 'Technology Strategies for Economic Development in a Fast Changing Global Economy', Economics of Innovation and New Technology, 11, 275-320.

Wiedersheim-Paul, E., Olson, H y Welch, L. (1978). Pre-Export Activity: The First Step in Internationalization. Journal of International Business Studies, Spring/Summer, pp. 47-58.

Zia, B. H. (2008). Export incentives, financial constraints, and the (mis)allocation of credit: Microlevel evidence from subsidized export loans. Journal of Financial Economics, 87, 498-527. 